\title{
EFFECT OF FLY ASH ON THE PROPERTIES OF CEMENT
}

\author{
Umesh Sharma ${ }^{1}$, D. Rastogi ${ }^{2}$ \\ Civil department MITS Gwalior474005, India ${ }^{1,2}$, Sharmaumesh729@gmail.com,deepak_rstg_mits@yahoo.co.in
}

\begin{abstract}
Effect of fly ash on the properties of cement. This experimental work is an effort to try to develop the awareness \& importance trial waste management \& its utilization in productive manner among the people. In today's more environmentally-Conscious world, a more responsible approach to the environment is to increase the use of by-products of one industry which is disposed off as waste as row material for some other industry developed countries have made rapid strides in the utilization of supplementary Cementitious material in cement and concrete. lack of awareness, consumer preferences, negative marketing strategies \& Lot of missunderstanding among the people have impeded their utilization in our country. In this work I have chosen fly ash for blending with Portland cement Viz. Fly ash. This waste after grinding properly was blended with ordinary Portland cement in different proportions. Then that blended cement was tested for various properties of cements such as fineness, Standard Consistency, Soundness, Setting time \& Compressive Strength. As the waste in powder form is of cementitious materials, they are proved to be best when blended with cement. I have got improved results related to most of the properties of cement as compared to that of ordinary Portland Cement. As industrial wastes pose a big problem of their disposal such waste can be blended with cement, bringing economy in Construction industry. So such waste can be blended with Cement, is the step towards economy \& obviously towards progress of the nation.
\end{abstract}

Keywords:-fly ash; experiments on blended cement with different proportions; cost comparison.

\section{INTRODUCTION}

\section{FLY ASH:-}

Fly ash is finally divided by product obtained from the combustion of pulverized coal in suspension fired furnaces of thermal plant or we can simply called, it as waste residue from thermal power stations. There are 70 thermal power stations in our India. Waterpower projects are comparatively very less.

Our country produces about 80 M.T. of coal ash per annum in various coal based thermal power stations. The disposal of such a large quantity of ash involves substantial expenditure in addition to locking up valuable land adjoining the power stations used as dumping ground. In addition to substantial initial capital expenditure on the infrastructure for transportation of the ash from the power station to the dumping ground. With targeted development programmed in the energy sector during $9^{\text {th }}$ plan period, the fly ash generation is expected to reach a level of over 110 M.T. per year by 200 $\mathrm{AD}$; Which would require on estimated on 28300 hectares of lands just for dumping. As result; environmental planner are facing greater challenges in preventing the degradation of environment and land being cost by fly ash dumps around thermal power stations all over India. Up till now government has incurred lot of money over disposal of fly ash. But dumping in ground is not an ECO-FRIENDLY solution. The ash dump pollutes the subsoil and renders the surrounding are unfit for cultivation.

The increase level of fly ash is linked to air, water and land pollution; Eroding structural surface, causing respiratory problems due to continued inhalation of the polluted air. For comparison, developed countries like U.K., Germany, France, Poland and China utilize heavily $60-70 \%$ of fly ash in their construction programme. At present; India is one of the lowest among the country of the world in the ash utilization. Only $30 \%$ of ash is being utilized in some projects in India. In spite of serious and concerted effort made by Union Govt. and state government technology mission fly ash disposal and utilization, there is no significant improvement in effective and large scale utilization of fly ash.

No doubt we have a fly ash mission at the national level and large number of other institution are involved in prompting the use of flay ash. The accent appears to be on encouraging use of fly ash for making bricks, road fills etc. which do not generate volume usage. Unfortunately there is no focus on the need for generating concrete quality fly ash.

The thermal power plants contained that the ash is just a byproduct and that it is not one of therefore activities to process and supply concrete grade fly ash. In the UK For instance a pulverized fly ash processing and supply industry has emerged, separate from the cement industry.

For testing work, fly ash which is used for blending with Portland cement are as given below : -

\subsection{Pulverized fly ash}

For making blended cement, following proportions are preferred:- 
(1) $50 \% \mathrm{OPC}+50 \%$ Waste

(2) $60 \% \mathrm{OPC}+40 \%$ Waste

(3) $40 \% \mathrm{OPC}+60 \%$ Waste

The effect on the properties using different proportions have been studied and tabulated.

\subsection{Chemical analysis of Fly Ash: - [ From Dipnagar]}

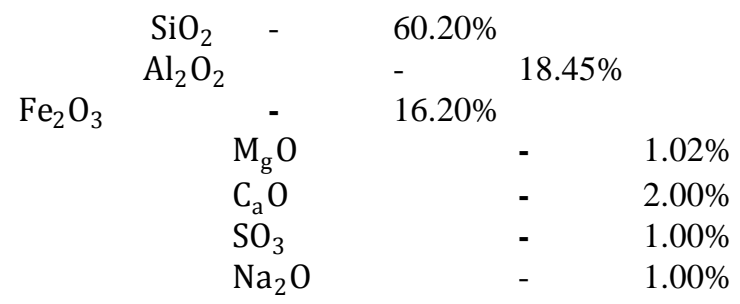

\subsection{CASE STUDY}

ASTM - C 618=93 categorizes fly ashes into the following three categories: -

1. Class N Fly ash: Raw or calcined natural pozzolans such as some diatomaceous earths, opalinechert and shale, stuffs, volcanic ashes and pumice come in this category. Calcined kaolin clay and laterite shale also fall in this category of pozzolans.

2. Class F Fly ash: Fly ash normally produced from burning anthracite or bituminous coal falls in this category. This class of fly ash exhibits pozzolanic property but rarely if any, selfhardening property.

3. Class C Fly ash: Fly ash normally produced from lignite or sub- bituminous coal is the only material included in this category. This class of fly ash has both pozzolanic and varying degree of self cementitious properties. (Most class $\mathrm{C}$ fly ashes contain more than $15 \% \mathrm{CaO}$. But some class $\mathrm{C}$ fly ashes may contain as little as $10 \% \mathrm{CaO}$.

\section{TESTS ON BLENDED CEMENT:}

\subsection{STANDARD CONSISTENCY OF CEMENT}

\section{RESULTS}

First Class Fly Ash

Table No.T 1

\begin{tabular}{|c|c|c|c|}
\hline Proportion & $\begin{array}{c}\text { Wt.of Cement } \\
\text { (gms.) }\end{array}$ & $\begin{array}{c}\text { Qty.of water } \\
\text { Added } \\
\text { (ml) }\end{array}$ & $\begin{array}{c}\text { Penetration from } \\
\text { top } \\
(\mathbf{m m})\end{array}$ \\
\hline \multirow{2}{*}{$50 \%$ OPC } & 200 & $50(25 \%)$ & 21 \\
\cline { 2 - 4 }+ & 200 & $52(26 \%)$ & 29 \\
\cline { 2 - 4 } $50 \%$ FLY \\
ASH.
\end{tabular}

Table No.T 2

\begin{tabular}{|c|c|c|c|}
\hline Proportion & $\begin{array}{c}\text { Wt.of Cement } \\
\text { (gms.) }\end{array}$ & $\begin{array}{c}\text { Qty.of water } \\
\text { Added } \\
(\mathbf{m l})\end{array}$ & $\begin{array}{c}\text { Penetration } \\
\text { from top } \\
(\mathbf{m m})\end{array}$ \\
\hline \multirow{2}{*}{$\begin{array}{c}60 \% \text { OPC } \\
+\end{array}$} & 200 & $46(23 \%)$ & 19 \\
\cline { 2 - 4 } & 200 & $48(24 \%)$ & 27 \\
$40 \%$ FLY \\
ASH.
\end{tabular}

Table No.T 3

\begin{tabular}{|c|c|c|c|}
\hline Proportion & $\begin{array}{c}\text { Wt.of Cement } \\
\text { (gms.) }\end{array}$ & $\begin{array}{c}\text { Qty.of water } \\
\text { Added } \\
(\mathrm{ml})\end{array}$ & $\begin{array}{l}\text { Penetration } \\
\text { from top } \\
(\mathrm{mm})\end{array}$ \\
\hline $40 \% \mathrm{OPC}$ & 200 & $56(28 \%)$ & 23 \\
\hline \multirow{3}{*}{$\begin{array}{c}\text { 60\%FLY } \\
\text { ASH. }\end{array}$} & 200 & $58(29 \%)$ & 29 \\
\hline & 200 & $60(30 \%)$ & 35 \\
\hline & \multicolumn{3}{|c|}{ Standard Consistency $=30 \%$} \\
\hline
\end{tabular}

\subsection{FINENESS OF CEMENT TEST RESULTS}

First Class Fly Ash

Table No.T 4

\begin{tabular}{|c|c|c|c|}
\hline Proportions & $\begin{array}{l}\text { Wt. of } \\
\text { cement }\end{array}$ & $\begin{array}{l}\text { Wt. of } \\
\text { residue left } \\
\text { on sieve }\end{array}$ & $\begin{array}{l}\text { Fineness } \\
\text { of } \\
\text { cement }\end{array}$ \\
\hline $50 \%-50 \%$ & $100 \mathrm{gm}$ & $7 \%$ & $93 \%$ \\
\hline $60 \%-40 \%$ & $100 \mathrm{gm}$ & $5 \%$ & $95 \%$ \\
\hline $40 \%-60 \%$ & $100 \mathrm{gm}$ & $4 \%$ & $96 \%$ \\
\hline
\end{tabular}

Second Class Fly Ash

Table No.T 5

\begin{tabular}{|c|c|c|c|}
\hline Proportions & $\begin{array}{l}\text { Wt. of } \\
\text { cement }\end{array}$ & $\begin{array}{l}\text { Wt. of } \\
\text { residue } \\
\text { left on } \\
\text { sieve }\end{array}$ & $\begin{array}{l}\text { Fineness } \\
\text { of } \\
\text { cement }\end{array}$ \\
\hline $50 \%-50 \%$ & $100 \mathrm{gm}$ & $12 \%$ & $88 \%$ \\
\hline $60 \%-40 \%$ & $100 \mathrm{gm}$ & $10 \%$ & $90 \%$ \\
\hline $40 \%-60 \%$ & $100 \mathrm{gm}$ & $15 \%$ & $85 \%$ \\
\hline
\end{tabular}


Third Class Fly Ash

Table No.T 6

\begin{tabular}{|c|c|c|c|}
\hline Proportions & $\begin{array}{l}\text { Wt. of } \\
\text { cement }\end{array}$ & $\begin{array}{l}\text { Wt. of } \\
\text { residue left } \\
\text { on sieve }\end{array}$ & $\begin{array}{l}\text { Fineness } \\
\text { of } \\
\text { cement }\end{array}$ \\
\hline $50 \%-50 \%$ & $100 \mathrm{gm}$ & $20 \%$ & $80 \%$ \\
\hline $60 \%-40 \%$ & $100 \mathrm{gm}$ & $18 \%$ & $82 \%$ \\
\hline $40 \%-60 \%$ & $100 \mathrm{gm}$ & $25 \%$ & $75 \%$ \\
\hline
\end{tabular}

\subsection{INITIAL AND FINAL SETTING TIME OF}

\section{CEMENT}

First Class Fly Ash

Table No.T 7

\begin{tabular}{|c|c|c|}
\hline PROPORTIONS & $\begin{array}{c}\text { INITIAL } \\
\text { SETTING TIME }\end{array}$ & $\begin{array}{c}\text { FINAL } \\
\text { SETTING TIME }\end{array}$ \\
\hline $\begin{array}{c}\mathbf{5 0 \% O P C}+50 \% \mathrm{FLY} \\
\text { ASH }\end{array}$ & 51 MIN. & 372 MIN. \\
\hline $\begin{array}{c}60 \% \text { OPC+40\%FLY } \\
\text { ASH }\end{array}$ & 47 MIN. & 405 MIN. \\
\hline $\begin{array}{c}40 \% \text { OPC+60\%FLY } \\
\text { ASH }\end{array}$ & 54 MIN. & 342 MIN. \\
\hline
\end{tabular}

\section{SOUNDNESS OF CEMENT TEST}

RESULTSMATERIAL=200gm

First Class Fly Ash100gm OPC, 100gm fly ash

Table No.T 8

\begin{tabular}{|l|l|l|l|l|}
\hline $\begin{array}{l}\text { Proportion } \\
\text { S }\end{array}$ & $\begin{array}{l}\text { Dist. } \\
\text { between } \\
\text { two } \\
\text { indicato } \\
\text { r arm } \\
\text { before } \\
\text { setting }\end{array}$ & $\begin{array}{l}\text { Dist. } \\
\text { between } \\
\text { two } \\
\text { indicato } \\
\text { r arm } \\
\text { after } \\
\text { setting }\end{array}$ & $\begin{array}{l}\text { Expansio } \\
\mathbf{n}\end{array}$ & $\begin{array}{l}\text { Remark } \\
\text { s }\end{array}$ \\
\hline $50 \%-50 \%$ & $20 \mathrm{gm}$ & $24 \mathrm{~mm}$ & $4 \mathrm{~mm}$ & Sound \\
\hline $60 \%-40 \%$ & $20 \mathrm{gm}$ & $25 \mathrm{~mm}$ & $5 \mathrm{~mm}$ & Sound \\
\hline $40 \%-60 \%$ & $20 \mathrm{gm}$ & $24 \mathrm{~mm}$ & $4 \mathrm{~mm}$ & sound \\
\hline
\end{tabular}

\section{COMPRESSIVE STRENGTH OF CEMENT}

First Class Fly AshOPC $=90$ gms, First Class FLY ASH. $=90$ gms.

\section{$4.150 \%$ OPC+50\% FLY ASH}

Table No.T 9

\begin{tabular}{|c|c|c|}
\hline After & \multicolumn{2}{|c|}{ Compressive Strength } \\
\hline & Load ( Tons) & $\left(\mathbf{K g} / \mathbf{c m}^{\mathbf{2}}\right)$ \\
\hline 7 days & 18.5 & 185 \\
\hline 14 days & 21.25 & 212.5 \\
\hline 28 days & 23.5 & 235 \\
\hline
\end{tabular}

$4.260 \%$ OPC+40\% FLY ASH. FLY ASH. $=72$ gms.

$$
\mathrm{OPC}=108 \mathrm{gms}
$$

Table No.T 10

\begin{tabular}{|c|c|c|}
\hline \multirow{2}{*}{ After } & \multicolumn{2}{|c|}{ Compressive Strength } \\
\hline & Load ( Tons) & $\left(\mathbf{K g} / \mathbf{c m}^{2}\right)$ \\
\hline 7 days & 20.4 & 204 \\
\hline 14 days & 24.5 & 245 \\
\hline 28 days & 27.3 & 273 \\
\hline
\end{tabular}

\section{$4.340 \%$ OPC+60\% FLY ASH. \\ $\mathrm{OPC}=72 \mathrm{gms}$,} FLY ASH. $=108$ gms.

Table No.T 11

\begin{tabular}{|c|c|c|}
\hline After & \multicolumn{2}{|c|}{ Compressive Strength } \\
\hline & Load ( Tons) & $\left(\mathbf{K g} / \mathbf{c m}^{\mathbf{2}}\right)$ \\
\hline 7 days & 17.8 & 178 \\
\hline 14 days & 20.9 & 209 \\
\hline 28 days & 27.8 & 278 \\
\hline
\end{tabular}

\section{COST COMPARISON}

Blended cement is definitely cheaper than ordinary Portland cement.Blended cement can be made in different proportions of ordinary Portland cement with fly ash. As waste is useless and having no value, saving is to be seen clearly. Only transportation cost, we have to pay to for bringing waste from source to the manufacturing place from where we can bring it. 


\begin{tabular}{|c|l|}
\hline \multicolumn{1}{|c|}{ Wastes } & Source \\
& \\
\hline (1) Pulverized fly & Thermal \\
ash & Power station \\
& at Dipnagar. \\
& Tal. \\
& Bhusawal, \\
& Dist. Jalgaon \\
\hline
\end{tabular}

The sources considered with study is from Maharashtra. In other states also similar sources for getting quality wastes might be available. But above sources are nearby with us so we have brought all the waste sample from there. For cost comparison between ordinary Portland cement and blended cement. We will consider $1 \mathrm{M}^{3}$ of concrete.In blended cement, we will consider fly ash first Proportion of $50 \%$ of O.P.C. With $50 \% 1$ st class FLY ASH. is the best proportion among the all proportions tested by me.

For $1 \mathrm{M}^{3}$ concrete [1:2:4]

\begin{tabular}{|l|c|c|}
\hline Material & & Qty. \\
\hline Cement & -- & $\begin{array}{c}0.22 \mathrm{M}^{3} \\
{[6.5 \mathrm{bags}]}\end{array}$ \\
\hline O.P.C. & -- & $3.25 \mathrm{bags}$ \\
\hline FLY ASH. & -- & $3.25 \mathrm{bags}$ \\
\hline Sand & -- & $0.44 \mathrm{M}^{3}$ \\
\hline $\begin{array}{l}\text { Course } \\
\text { Aggregate }\end{array}$ & - & $0.88 \mathrm{M}^{3}$ \\
\hline
\end{tabular}




\section{Cost comparison as per current rate}

\begin{tabular}{|c|c|c|c|c|c|c|c|c|c|c|c|}
\hline \multicolumn{6}{|c|}{ O.P.C Concrete } & \multicolumn{5}{|c|}{ Blended Cement Concrete } & \multirow[t]{2}{*}{ Remark } \\
\hline & $\begin{array}{l}\text { Materia } \\
1\end{array}$ & Qty. & $\begin{array}{c}\mathrm{Ra} \\
\text { te }\end{array}$ & Per & Amt. & $\begin{array}{c}\text { Materia } \\
1\end{array}$ & Qty. & Rate & Per & Amt & \\
\hline \multirow[t]{2}{*}{ 1) } & \multirow[t]{2}{*}{ O.P.C } & \multirow[t]{2}{*}{$\begin{array}{l}0.22 \mathrm{M} \\
{[6.5} \\
\text { bags }]\end{array}$} & \multirow[t]{2}{*}{$\begin{array}{c}30 \\
0\end{array}$} & \multirow[t]{2}{*}{ Bag } & \multirow[t]{2}{*}{1950} & O.P.C & $3.5 \mathrm{Bag}$ & 300 & Bag & $\begin{array}{c}105 \\
0\end{array}$ & $\begin{array}{l}\text { FLY ASH. } \\
\text { from } \\
\text { thermal } \\
\text { power } \\
\text { station } \\
\text { dipnagar }\end{array}$ \\
\hline & & & & & & $\begin{array}{l}\text { FLY } \\
\text { ASH. }\end{array}$ & $3.5 \mathrm{Bag}$ & -- & -- & -- & \\
\hline 2) & Sand & $0.44 \mathrm{M}$ & $\begin{array}{c}28 \\
5\end{array}$ & $\mathrm{M}^{3}$ & 125 & Sand & $0.44 \mathrm{M}^{3}$ & 285 & $\mathrm{M}^{3}$ & 125 & \\
\hline 3) & $\begin{array}{c}\text { Course } \\
\text { Aggreg } \\
\text { ate }\end{array}$ & $0.88 \mathrm{M}$ & $\begin{array}{c}42 \\
5\end{array}$ & $\mathrm{M}^{3}$ & 374 & C.A. & $0.88 \mathrm{M}^{3}$ & 425 & $\mathrm{M}^{3}$ & 374 & \\
\hline \multicolumn{6}{|c|}{ Rs. 2449} & \multicolumn{5}{|c|}{ Total } & \\
\hline
\end{tabular}




\section{For blended cement: -}

Transportation cost of FLY ASH. from source to the site $=$ Rs. 90/-[Rs. 500/Truck]

Total expenditure requires for making of $1 \mathrm{M}^{3}$ concrete with blended cement is Rs. 1549

$$
\text { Rs. 1639/- }
$$

Saving in the cost per $\mathrm{M}^{3}$ Concrete after using blended cement.

$=$ Rs. 2449-1549

= Rs. 900/-

Saving is the cost will be different at different places; depends upon distances of the sources of wastes.

\section{CONCLUSIONS}

After testing blended cement with different proportions, following conclusions are drawn:-

1. more fine than that of the plain Portland cement. But IInd class and IIIrd class fly ash are not liable for blending as they are coarser.

2. Standard Consistency of blended cement is comparatively less than that of ordinary Portland cement. It means that W/C. Ratio obtained is less than that of plain cement.

3. Fly ash proves to be best waste for blending with Portland cement as it increases initial setting time and decreases the final setting time of cement considerably.

4. Fly ash based blended cement is comparatively more sound.

5. In case of compressive strength, fly ash blended cement imparts more strength.

So blended cement proved as improved material as compared to O.P.C in all the properties of cement Blended cement is economical and Eco-friendly. There is lot of saving in energy consumption while manufacturing such cement.

\section{REFERENCES}

[1] Recommended guidelines of fineness of cement, IS 269:1976,Bureau of Indian Standards, New Delhi

[2] Method of tests for standard consistency of cement, IS 4031:1968, Bureau of Indian Standards, New Delhi.

[3] Initial setting time and final setting time of cement method of test, IS 269:1967/1975,Bureau of Indian Standards, New Delhi

[4] Compressive strength of cement method of test, IS 650:1969, Bureau of Indian Standards, New Delhi
[5] M.S. Shetty, "Concrete Technology Theory and Practice" S. Chand and Company Ltd., New Delhi, 2006.

[6] M.L. Gambhir, "Concrete Technology”, Tata McGrawHill Publishing Company Limited, New Delhi, 2006

[7] Caijun Shi, Yanzhhhong Wu, Chris Riefler, and Hugh Wang, "Characteristics and pozzolanic reactivity of glass powders", Cement and Concrete Research 35(2005)

[8] V. M. Malhorta and P. K. Mehta, "High performance high volume fly ash concrete: materials, mixture proportioning, properties, construction practice and case histories", Ottawa, Canada, 2002.

[9] M. L. D. Gougar, B. E. Scheetz and D. M. Roy - Waste Management, 1996, 16(4), 295-303.

[10] European standard EN 196-3: 1994: Method of Testing Cement. Part 3: Setting time and Soundness.

[11] B. D. Bone, L. H. Barnard, D. I. Bortdman, P. J. Carey, C. D. Hills, H. M. Jones, C. L. MacLeod and M. Tyrer, "Review of scientific literature on the use of stabilization/solidification for the treatment of contamined soil, solid waste and sludges", Science Report SC 980003/SR2 - Environment agency U.K. 